\section{Pedagogical injustice and counter-terrorist education}

\author{
Aislinn O'Donnell
}

Maynooth University, Ireland
Education, Citizenship and Social Justice

2017, Vol. 12(2) 177-193

(C) The Author(s) 2017

Reprints and permissions:

sagepub.co.uk/journalsPermissions.nav

DOI: $10.1177 / 1746197917698490$

journals.sagepub.com/home/ecsj

(S)AGE

\begin{abstract}
This article addresses the way in which the securitisation of education, effected through initiatives in counter-terrorism such as Prevent, leads to what I call 'pedagogical injustice' for students and teachers. It analyses the implications of the pre-crime agenda in the space of the classroom and draws upon literature on epistemic injustice, communicative injustice and institutional prejudice to explain why bringing counterterrorist legislation into education undermines the educational endeavour. It argues that by re-framing the Prevent agenda in the language of therapy, resilience and well-being, indicators guiding its implementation that might otherwise be seen as illegitimate or even illegal forms of profiling are given credence in the spheres of education and other domains which demand pastoral care from professionals. By targeting ideas instead of focusing on violence, Prevent undermines educators. Foucault describes this kind of blurring of discourses as ubuesque and examines the veneer of legitimacy given when professionals engage in discourses and practices beyond their specific expertise. This new figure is the counter-terrorist educator operating between the spheres of security, psychology and education. To contest this image of education and outline the dangers of this approach, we turn to Arendt's writings on education and her commitment to 'training the imagination to go visiting'.
\end{abstract}

\title{
Keywords
}

Arendt, counter-terrorism, education, epistemic injustice, Foucault, fundamental British values, pedagogical injustice, Prevent, securitisation, Ubu

\section{Introduction}

Nothing is a risk in itself; there is no risk in reality. But on the other hand, anything can be a risk; it all depends on how one analyses the danger, considers the event. (Ewald in Burchell et al., 1991: 199)

This essay discusses the example of Prevent, one of the strands of the UK Counter-terrorism strategy (CONTEST), to show how its implementation can be seen as an instance of what I call 'pedagogical injustice'. I have previously written about the risk of epistemic injustice when counter-terrorist and securitising agendas infiltrate educational discourse and practice (O'Donnell, 2016). Here I wish to refine this analysis by introducing the concept of pedagogical injustice. The concept of 
pedagogical injustice can help draw out some of the ways in which counter-terrorist strategies can undermine pedagogy, trust and dialogue; the pursuit of knowledge and understanding; the space for thinking; and the potentials of educational relationships. Non-ideal approaches to theoretical and philosophical questions invite us to perceive the failings in our practices and to thereby locate the potentials for transformation of practice. Reflecting on pedagogical injustice also helps us to locate violations in human rights in schools and educational institutions through the intrusion of counterterrorist approaches into the educational space (Rights Watch UK, 2016).

In the first half of the essay, I will explain the concept of pedagogical injustice in relation to the concept of epistemic injustice. I will then outline some of the ways in which education is being securitised, paying particular attention to the use of risk assessment tools, and the implications of these for the educational experience, focusing particularly on the implications for the exchange of ideas, student voice and pursuit of knowledge. I mobilise Foucault's concept of the Ubu to show how the securitisation of education is effected and explain why I understand this to be an instance of pedagogical injustice. I then extend this argument by drawing upon Fricker's (2012) essay on silence and institutional prejudice in order to consider ways in which student may not be heard or listened to or may self-censor. I conclude the essay by briefly focusing on two aspects of pedagogical justice that offer, I argue, a robust pedagogical response to the strategy of countering extremist ideas: cultivating the 'enlarged mentality' of which Arendt speaks, whereby one trains one's imagination to go visiting; developing the capacity for sensitive and careful listening and creative attention, of which Fricker speaks.

It should not be forgotten that Prevent is part of a wider counter-terrorism strategy, and this alone should give pause for thought for educators, parents and students. In respect of preventative counter-terrorism, McCulloch and Pickering (2009) explain that "[t]he "preventive" counterterrorism framework is concerned less with gathering evidence, prosecution, conviction and subsequent punishment than in targeting and managing through disruption, restriction and incapacitation those individuals and groups considered to be a risk' (p. 631). What are the implications of this approach for students in classrooms, in particular when educators are asked to appraise the ideas and views of their students through the lens of a securitised framework of surveillance that is presented as safeguarding, in which intentionally or not Muslims are profiled as a special 'at-risk' category. The literature, policy documentation and training that accompany Prevent foreground Muslims (Rights Watch UK, 2016: 10). In the global context, recent developments in the Trump administration in the United States include proposals that Countering Violent Extremism (CVE) programmes will focus solely on 'Countering Radical Islamic Extremism'. One ought to be vigilant about such incremental shifts and the risk of institutionalised Islamophobia. It is also important to remember that schools and universities took their responsibilities of pastoral care and safeguarding seriously long before Prevent and that they already engage in multi-agency partnerships to support students at risk.

Looking at counter-terrorist education through the lens of the concept of pedagogical injustice helps to reveal how certain kinds of means and ends, for instance, indoctrination or securitisation, have a direct impact on the possibility of pursuing pedagogical relationships and educational practice. Imposing such ends or demanding their incorporation into education practice, as in the case of securitisation, makes it difficult to pursue, or to justify the pursuit of, educational goods for their own sake, to extend one's imagination and to create the conditions for truthful, honest and trusting relationships between educators, parents and students. Securitisation and indoctrination involve different aims, but both stymie thought and speech in classrooms. One consequence of securitisation (intended or otherwise) is uncertainty and doubt about both what can be said and how to interpret what is said, while the aim of indoctrination is to assure unquestioned certainty by refusing to expose students to alternative ideas, values or bodies of knowledge. In so doing, both securitisation 
and indoctrination fatally undo the educational endeavour. Why? In the case of securitisation, as we will see, it is because neither teacher nor student can fully know which ideas, views, interpretations and thoughts are permissible. Given the lack of definition of key terms in Prevent and the latitude for interpretation of the 22 indicators of risk in the Channel Vulnerability Framework, it is not clear which ought to be seen as symptomatic of a 'risk of radicalisation'. Even if it is stated that classrooms should be safe spaces for the discussion of controversial issues, the equation of extremist ideas with terrorist pathways in the context of a pre-crime, preventative agenda risks an overzealous approach to implementation. In such contexts, 'hermeneutical injustice can mean that someone is socially constituted as, and perhaps even caused to be, something they are not, and which it is against their interests to be seen to be' (Fricker, 2007: 168).

\section{Pedagogical injustice and epistemic injustice}

The concept of epistemic injustice offers a lens through which to look at those educational wrongs that I argue accompany Prevent. That said, issues relating to Prevent in the educational context do not map straightforwardly onto the concept of epistemic injustice, in particular in relation to questions of testimony and credibility as these fail to capture the asymmetrical dynamic of the student's position as learner in the educational relationship. As such gauging credibility is not necessarily the primary concern of the teacher. Rather, cultivating understanding, being capable of reappraising one's position and engaging in critical reflection are the kinds of intellectual virtues one hopes to develop in classrooms. In this respect, the concept of pedagogical injustice can perhaps better articulate the impact on the dynamics of the pedagogical relationship in respect of the demands made by the legal duty of Prevent on educational institutions. To understand the similarities and differences between the two concepts, I will offer a brief exposition of key aspects of Fricker's (2007) concept of epistemic injustice with the caveat that differences from the concept of pedagogical injustice rest in the following: the student is understood not simply as knower but as learner; the professional judgement of the teacher can be undermined either by systematically doubting one's own judgement and perceptions because of being asked to read statements and contributions from students through a lens of a security agenda or by applying codified rules, such as looking for crude indicators of radicalisation; teachers may feel caught between competing demands: to respond ethically to the student by being a virtuous hearer and being compelled to deploy social stereotypes and identity prejudice (which they may not hold themselves) by enacting the Prevent duty. In the latter case, while Prevent claims that teachers' professional judgement must be used, it simultaneously promotes reliance on 'rules' qua behavioural criteria rather than judgement because it rewards risk aversion. The issue of the dual role I will discuss by examining it through the lens of Foucault's concept of the Ubu later in this essay.

Fricker (2007) describes testimonial injustice as 'when prejudice causes a hearer to give a deflated level of credibility to a speaker's word' saying that 'an example [...] might be that the police do not believe you because you are black' (p. 1). In short, 'the basic idea is that a speaker suffers a testimonial injustice if prejudice on the hearer's part causes him to give the speaker less credibility than he would otherwise have given' (Fricker, 2007: 4). This can be due to identity prejudice which leads to a credibility deficit. Our primary everyday epistemic practices involve 'conveying knowledge to others by telling them, and making sense of our own social experiences' (Fricker, 2007: 2), and these are affected by social power. The kind of wrong inflicted when someone is wronged in their capacity 'as a subject of knowledge, a giver of knowledge, and informant' (Fricker, 2007: 5) is one of epistemic injustice. Fricker (2007) acknowledges that any hearer in a testimonial exchange 'perceives her interlocutor in an epistemically charged way - she perceives him as credible to this or that degree' (p. 5), and the virtuous hearer will correct for identity 
prejudice. However, epistemic objectification occurs when someone is not heard as a speaker or is not heard as rational because of identity prejudice. Elements of identity prejudice and the risk of epistemic objectification are, I argue, at play in the Prevent strategy, not because teachers necessarily hold such social stereotypes individually but because systemically such identity prejudices underpin the Prevent Strategy, meaning that the contributions of some students may be overdetermined and misheard or because, to use Foucault's concept, they become 'doubles' as a consequence of the dual role that teachers are expected to play. That is, on one hand, teachers must educate students and, on the other hand, they must fulfil the duty to actively ward against or prevent terrorism by being alert to indicators that a student is at risk of radicalisation.

Fricker (2007) argues that for one subjected to persistent testimonial injustice, harm is done to them as a knower, such that 'this persistent intellectual undermining causes him to lose confidence in his beliefs and/or his justification for them, he literally loses knowledge' (p. 49). There is evidence, as we will see, that through fear of being misinterpreted, students, in particular Muslim students, are withdrawing from discussion of controversial issues or avoiding speaking their mind. They cannot trust their teachers to be virtuous hearers, sensitive to context and willing to make singular judgements if those same teachers are also being asked to report back on indicators of risk and if their schools are being inspected on such. By excluding students from trustful conversation, they are thus marginalised, unable to participate fully in their education (Sukarieh and Tannock, 2015). Likewise, the rights of their families to full citizenship in the form of free speech and the opportunity to question and deliberate political ideals and practices are undermined where there is a fear of systematic 'mishearing' that undoes the trust born of virtuous hearing and inclusive dialogue. Fricker discusses prejudicial stereotypes in classrooms and the ways in which credibility judgements are deflated when such stereotypes determine educational practice. This may indeed be the case, however, there is a supplementary matter of concern that relates to practices of deliberate withdrawal from participation by students for fear of being misheard (and thus referred) that impacts the possibility of full participation in the educational experience. This differs from Fricker's point regarding pre-emptive testimonial injustice (although that injustice may be at play in this context in respect of teachers). Students fear identity prejudice will give rise to systemic mishearing of their contributions and thus choose to remain silent to pre-empt this. They may also fear what Fricker (2007) calls 'situated hermeneutical inequality' (p. 162) in that they may doubt that will be able to render communicatively intelligible their own position if their statement are received through the lens of security concerns.

Of course, there is good anecdotal evidence of creative interpretations of Prevent, including responsive, contextual thinking and the astute use of professional judgement in schools in order to ensure responsible and virtuous hearing and refuse the crude application of rules, pre-set principles or codes. Notwithstanding this, it ought to be a matter of concern that such responses rely on considerable pedagogical skilfulness and the ability to offer comprehensive and considered reasons for such an approach, demonstrating what Fricker (2007) calls a trained testimonial sensibility that 'enables the hearer to respond to the word of another with the sort of critical openness that is required for a thoroughly effortless sharing of knowledge' (p. 85). Other schools and teachers less habituated to cultivating such epistemic virtues may simply decide to err on the side of caution and take refuge in what Fricker (2007) calls 'the bogus objectivity' (p. 73) of codifiability. What ought to be at the heart of education - dialogue - is fatally undermined once trust is withdrawn by one or both parties. The educational wrong here, which is why I have suggested this constitutes pedagogical injustice, is to the student as learner, and arguably to the teacher as teacher, and not simply to the student as giver or subject of knowledge. Both parties are precluded from full engagement in the act of learning, in particular the opportunity to exchange thoughts, ideas and reasons, and as a consequence students' right to education is undermined. In this regard, there is 'prejudicial 
exclusion from participation in the spread of knowledge' (Fricker, 2007: 162) or, more precisely in this case, in the encounter with knowledge.

\section{Policing ideas?}

Recent efforts to enact counter-terrorism strategies through educational institutions constitute a particular kind of educational wrong, regardless of the creative nature of pedagogical activities that may have been developed in response to the Prevent Duty. This is because those activities are understood, justified, legitimated and evaluated from the perspective of security rather than from the perspective of education and the student. Prevent is, of course, just one example of States' attempts to develop counter-radicalising and deradicalising initiatives in and through education by 'stopping people from becoming terrorists or supporting terrorism' (HM Government, 2015a: 3). It makes an explicit connection between terrorism and extremism and offers the following rationale for this approach and its definition of extremism:

Terrorist groups often draw on extremist ideology, developed by extremist organisations. Some people who join terrorist groups have previously been members of extremist organisations and have been radicalised by them. The Government has defined extremism in the Prevent strategy as: "vocal or active opposition to fundamental British values, including democracy, the rule of law, individual liberty and mutual respect and tolerance of different faiths and beliefs. We also include in our definition of extremism calls for the death of members of our armed forces'. (HM Government, 2015a: 3)

It is then stated that local authorities ought to produce counter-terrorism local profiles (CTLPs) to 'assess the risk of individuals being drawn into terrorism. This includes not just violent extremism but also non-violent extremism which can create an atmosphere conducive to terrorism and can popularize views which terrorists exploit' (HM Government, 2015a: 7). It is noted that

Schools should be safe spaces in which children and young people can understand and discuss sensitive topics, including terrorism and the extremist ideas that are part of terrorist ideology, and learn how to challenge these ideas. The Prevent duty is not intended to limit discussion of these issues. Schools should, however, be mindful of their existing duties to forbid political indoctrination and secure a balanced presentation of political issues. (HM Government, 2015a: 11, my emphasis)

However, the difficulty here is that it presents the ideology and motivation of 'the terrorist' as a monolithic story, precluding more sensitive, contextual and imaginative exploration of questions of political violence once it prescribes that the purpose of the discussion is to challenge rather than explore or critically evaluate the extremist ideas (of the terrorist). Educators are often committed to creating the conditions for contestation and debate in classrooms, however, it is problematic when institutions are asked to justify and frame their practice with reference to a security agenda. Indeed, Arendt (1961) cautions strongly that education ought not be used for political ends of any kind. Here, she had in mind the tendency to use education as a tool to solve society's problems and to create political utopias. She would have been deeply critical of and concerned by the idea that security and surveillance ought to play a role in education given her own history and the implications of this for students' capacities to think and to judge. However, while Arendt resists the instrumentalisation of education in the service of political agendas, she writes about the virtues, both intellectual and ethical, of thinking, judging, understanding and so forth, and her attentiveness to: developing complex deep understanding of subject matter, thinking for oneself and cultivating a sense of historical sensibility and love of the world, exemplifies why she sees teachers as responsible for the world, viewing education as a particular kind of 'ethical' 
relationship between the generations. One need not directly teach citizenship in order to help students to 'love the world'.

Education, as distinct from indoctrination, involves exploring and challenging all sorts of ideas as part of a process of critical enquiry and coming to understand one's subject matter more deeply. However, the tenor of this iteration of Prevent guidance (HM Government, 2015b) does not appear to suggest that instances of State terrorism could be investigated or that it is possible that sometimes the law ought to be disobeyed - this might run contrary to the requirement to promote Fundamental British Values, even if creative educators have taken the opportunity to introduce such discussions in a more nuanced fashion. If we take seriously the guidance, how ought we respond to and understand protests against slavery, the miners' strikes, the suffragette movement, Occupy and so forth, all instances of historical law-breaking? Underlying the language of 'challenging' rather than 'exploring' is the suggestion that there is a 'right answer' that students ought to give. Deciding how one might challenge extremism, and indeed whether certain kinds of 'extremist ideas' ought to be challenged, depends ultimately on the definition of extremism and how it is interpreted. If we recall Martin Luther King's Letter from a Birmingham Gaol, there he identifies himself as both an extremist, like Socrates and Jesus, and as someone who will question unjust laws. However, in the Prevent Guidance, extremism and references to radicalisation are equated with terrorism. The fact that non-violent extremism is defined negatively as 'extremism that is not accompanied by violence' is unsatisfactory (Bartlett and Birdwell, 2010) as it fails to secure the difference between ideas and violence, in particular given the lack of evidence for conveyor-belt theories of radicalisation (Horgan, 2008).

The success of the Prevent agenda, it is stated, will be assured through 'communities supporting efforts to prevent people being drawn into terrorism and challenging the extremist ideas that are also part of terrorist ideology' (HM Government, 2015b: 20). The Learning Together to be Safe Toolkit (Department for Children, Schools, and Families, 2008), published before the latest iterations of Prevent, describes the purpose of anti-extremist education in schools in terms of challenging violent extremism. Its adherence to a pathway approach to radicalisation means that it risks conflating extremist narratives and views with violent extremism: it uses a pyramid, tiered approach that implicitly references non-violent extremism, however, the document emphasises the need to address violent extremism. It does, however, make clear that "The Government has a "Prevent" strategy as part of its overall approach to countering terrorism with the aim of preventing people becoming terrorists or supporting violent extremism' (DCSF, 2008: 13; my emphasis). Despite such limitations, it offers a more nuanced and considered approach than the more recent guidance, such as Prevent Guidance (2015b), and it claims to value and privilege the professional judgement of educators.

Most importantly in respect of pedagogical injustice is Prevent's focus on non-violent extremism: the express target is the domain of ideas and beliefs. What is at stake here is not simply surveilling actions, behaviours or even identifying the intent to engage in violent extremism or terrorism. Prevent's strategy rests on the (unfounded) assumption that certain kinds of (extreme) ideas and ideologies have a direct causal relationship with political violence. Recent Department for Education Statutory Guidance (2016) lists the 'risk of radicalisation' (which presumably is concerned with susceptibility to extremist ideas) alongside other understandable safeguarding issues such as violence, abuse and neglect (House of Lords, House of Commons, Joint Committee, 2016), all of which have both an evidence-base underpinning intervention as well as clear referents for categorisation. Conversely, as Ewald in our opening quote suggests, the vulnerability factors, risk factors and indicators outlined in Prevent and Channel could render almost any behaviour, speech or expression of identity a sign of being 'at risk of radicalisation'. 
By creating a provisional symptomatology of traits that seeks to locate those who may be carriers of extremist ideas, Prevent risks a pernicious form of pedagogical injustice. It brings security and surveillance explicitly into the world of ideas, knowledge and enquiry, a domain most precious to those who value independence of thought, critical thinking, attentive listening, virtuous hearing, imagination and enquiry. It undoes the possibility of creating educational spaces that allow for disagreement, conflict, storytelling and reflection once students feel they may be at risk of referral if they air views that are seen as controversial (Human Rights UK, 2016). It is important to note that this takes place in a wider context of surveillance and suspicion (O'Toole et al, 2016), and we ought to be minded of Fricker's writings on systematic testimonial injustice and hermeneutical injustice. Mythen (2012) describes the frustration and difficulty faced by young British Pakistani males who have little opportunity 'to express their political viewpoints, share their frustrations about the personal impacts of national security measures or publically object to British foreign and military policy' (p. 412) because of the ways in which they feel under suspicion and under surveillance. One group of young Muslims from North West England feel that they are a 'suspect community'. Rabiya says, 'I think we are restricted when it comes to saying what we think. If you're Muslim, people don't let you get away with challenging what this country is doing any more. If you do, you're seen as a fanatic' (Mythen et al., 2012: 393). Their descriptions of self-censorship and of their efforts to present an outwardly safe identity, as well as their tendency to curtail their speech because of fears of being labelled a terrorist sympathiser, remind us that when reflecting on strategies like Prevent, one cannot pretend that the school is divorced from wider society or that students will remain unaffected by being positioned as 'suspect' or 'risky'. The effects of this wider climate provide a challenge for educators seeking to ensure that students have voice, in particular those who feel that they have been framed as a 'suspect community' (Pantazis and Pemberton, 2009; Awan, 2012). In this respect, educators should work at knowing their students in their singularity. This involves the refinement of a moral perception that supports contextual judgements and that enables epistemic negotiations that are responsive to situational specificity (Code, 2006) while refusing deficit approaches (Van San et al., 2013), prejudice or stereotype. An essential part of this will be listening attentively, or what Fricker calls 'virtuous hearing'.

The need for contextual judgement and 'situated impartiality' is reiterated through Arendt's $(1955,1958,1971,1990,1991)$ work. In her essay 'The Crisis in Education', she says that a crisis becomes a disaster only 'when we respond to it with preformed judgements, that is, with prejudices' (Arendt, 1961: 174). The difficulty is of course how one will judge given the claim that there exist supposedly evidence-based indicators that may flag possible risks of radicalisation. In such a case, how can one develop the capacity for contextual, considered thinking and self-awareness that is needed in order to make a judgement? The latitude for interpretation of such risk factors, in particular under the heading of Intent, means that even if just some educators think of them as discrete, codified and technical indicators of risk, perhaps because of a well-meaning concern to safeguard children or the desire to act pre-emptively because of the fear of the consequences of not doing so for the student and family, this risks an overly vigorous relationship to referrals. We have to be concerned that $93 \%$ of referrals to Channel were rejected in 2015, a drop of $13 \%$ from the previous rate, in the context of a significant increase in numbers of referrals, a third of which are by educators. Unfortunately, despite extensive literature in this regard, there has been a failure to acknowledge racialised, gendered and classed histories and presents; the relationships between bodies marked with different histories; the contemporary context and discourses about terrorism; and the presuppositions and prejudices that educators bring with them into classrooms and the ways these may influence referral rates.

Laura Hengehold underscores the role of the political imagination in our aesthetic responses to different bodies. She says, 'political imagination can also mean the range of actions people believe 
are possible in a given historical situation. Institutional beliefs, problems, and habits together comprise a "problematic" in which bodies are caught, or whose coherence they must support' (Hengehold, 2007: 282-283). We are limited by our political imaginations, and some of us are entrapped by the imaginations of others, perceived by our very existence as threats and endangerments to them. This is not simply a matter of personal prejudice but a function of institutions and structures that constitute some of us as risky. Understanding this, and understanding how this might feel for someone, is part of the job of what it means to educate. A further responsibility is to find ways of changing institutional spaces to allow the individuality of others to be seen, heard and listened to.

\section{Vulnerability and threat}

Anticipating risk or threat, and the inevitable profiling that accompanies it, while maintaining a veneer of scientific objectivity is animated through the lens of prejudice. The pre-crime project relies less on 'joining the dots' or putting the pieces of a puzzle together - metaphors that suggests some underlying pattern than a wholly unscientific project of crystal ball gazing. (McCulloch and Pickering, 2009: 635)

A forceful statement that the infiltration of security discourses into the educational domain constitutes an immediate violation of the right to education, as well as other human rights such as the right to participation and the right to freedom of expression, has been made in a report by Rights Watch UK (2016). It suggests that Prevent makes it difficult to have complex, contested and indeed open conversations, in particular in the case of Muslim students who are fearful of being misinterpreted or of speaking critically. If this is the case, and there is a growing body of literature that suggests that it is, this will have a bearing on the capacity for deep and critical understanding of content knowledge because it undoes the conditions for trust and criticality that enable us to think and enquire together in shared educational spaces. In short, securitising education undermines the conditions that would otherwise foster trust, free speech, enquiry, thinking, understanding, imagination and judgement, all conditions for, and consequences of, 'good' education, as opposed to indoctrination or co-optation of education in the service of security agendas.

Rights Watch UK (2016) quotes the United Nations (UN) Special Rapporteur on the Rights to Freedom of Peaceful Assembly and of Association: 'It appears that Prevent is having the opposite of its intended effect: by dividing, stigmatizing and alienating segments of the population, Prevent could end up promoting extremism, rather than countering it' (Rights Watch UK, 2016: 2). Both Rights Watch UK and the Open Society Justice Initiative's (OSJI) (2016) recently issued reports on the Prevent Strategy condemned the strategy from a human rights perspective, with Rights Watch UK (2016) stating that

Prevent has led to violations of the right to education, the right to freedom of expression, the right to freedom of religion, the right to privacy, the right to freedom from discrimination, and the fundamental principle that actions taken in relation to children must treat the child's best interests as a primary consideration. (p. 4)

The OSJI (2016) details a range of case studies describing the impact of the Prevent strategy and Channel referrals on the lives of parents, teachers and children. Indeed, Rights Watch UK describes Prevent in the most forceful of terms as creating a 'chill factor' and an atmosphere of self-censorship. In another critical report, Belaon (2015) discusses Building Resilience Through Integration and Trust (BRIT), understood by local parents to be an instance of crude ethnic profiling, but framed as a project about community cohesion, and operating, he argues, as a covert instance of the 
Prevent agenda, using the pyramid model of Learning Together to be Safe to conceptualise radicalisation.

The Joint Committee (2016) also notes that

The Government now proposes to put its counter-extremism proposals in the context of 'safeguarding'. Everyone can understand the definition of safeguarding when it comes to child neglect, physical abuse and sexual abuse. In relation to extremism, however, there is no shared consensus or definition as to what children would be safeguarded from. (p. 5)

This lack of clarity, combined with the familiar language of safeguarding, offers the comfort of the form of a familiar discourse (safeguarding) but without any secure referent or reliable mode of assessment. Blackwood et al. (2016) question the Workshop to Raise Awareness of Prevent (WRAP) training's tendency to focus on individual vulnerability, susceptibility and weakness, and its concomitant aim to support professionals in locating 'signs' of vulnerability. It should be noted that the concept of vulnerability is defined in Prevent as follows: 'the word describes factors and characteristics associated with being susceptible to radicalisation' (HM Government, 2015: 22). This is an empty definition of a central concept and operational tool in the Prevent strategy.

The lack of transparency about guidelines such as the National Offender Management Service's (NOMS) Vulnerability Framework Extremism Risk Guidance (ERG) 22+ is concerning. Andrew Belaon (2015) states that in response to his Freedom of Information Act (FOIA) to 26 local authorities and Ofsted asking for information about a number of aspects of intervention, including a request to 'Please provide a list of extremist thoughts, ideas, views, behaviours, influences and outlooks which such training advises has the potential to radicalise and which inform your working practices' (p. 7), Ofsted responded as follows:

We can neither confirm nor deny that we keep a list of extremist thoughts, ideas, views, behaviours, influences and outlooks, nor a list of organisations, groups and individuals which are considered to be extreme or support/preach extremism. [...] Disclosing information to the public about the details of training materials used to inform inspectors about how to be alert to signs of extremism or radicalisation in schools would potentially breach national security by allowing perpetrators to have sight of information which would not be in the public domain due to national security concerns. There is clearly a public interest in national security being maintained. (Belaon, 2015: 7-8)

It is not difficult to see the challenge here for both students and teachers: one cannot know what constitutes a sign of extremism or radicalisation on the grounds of national security, yet educators are nevertheless obligated to refer students who show such signs. It is deeply problematic that there is no transparency about the criteria used for assessment (Belaon, 2015; O'Donnell, 2016). This results in de facto mass profiling in educational institutions, and what is presented as safeguarding is effectively surveillance - it simply does not meet the standards or clarity required to identify risk, as the Joint Committee (2016) and the Home Affairs Committee (2016) underline, primarily because its target is ideas and the susceptibility thereto and because changes in behaviour, dress and so forth are so often simply part of developing one's identity. Tools, like ERG22+, that purport to help professionals identify vulnerabilities, lay claim to scientific credibility and legitimacy without having been subjected to the rigours of prior peer review and they do not offer transparency about the research process or methodology. Yet, these are the frameworks made available for reference to non-experts responsible for implementing Prevent - presumably those involved directly in adjudicating Channel referrals have specific expertise that enables them to make informed judgements. The OSJI (2016) quote Andrew Silke who clarifies that 'ERG is a theoretical model and, as yet, does not have an evidence base demonstrating clear links to future offending' (p. 39). Even 
though the Channel Guidance is clear about the limitations of this approach and even though it says 'there is no single route to terrorism nor is there a simple profile of those who become involved' (HM Government, 2015a: 12), the suggestion that these diffuse clusters of factors under the headings of Intent, Engagement and Capability may be useful in determining risk and identifying vulnerabilities gives them potency, compounded by perceived significant risk of ignoring risk.

Conceptualising the 'risk of radicalisation' under the aegis of 'safeguarding' permits of referrals that are 'pre-emptive and probabilistic, anticipatory and preventative, not based upon the diagnosis of pathology in an individual but on the actuarial analysis of risk factors' (Rose, 2004: 235). Rose (2004) argues that the individualisation of risk involves 'risk management strategies' that are conceived in probabilistic terms

[a]nd their aim is to act pre-emptively upon potentially problematic zones, to structure them in such a way as to reduce the likelihood of undesirable events or conduct occurring and to increase the likelihood of those types of events and activities that are desired. (p. 237)

Schinkel's (2011) concept of 'prepression' underlines that both prevention and repression are at play in pre-crime agendas. By tracking young people's lives 'in such a way as to stress certain images whilst suppressing alternatives [...] the actuarial workers of these archives are interested in selecting the best - that is: least "risky" - possible worlds and to prevent others from becoming real' (p. 373). The factors and indicators that are being mobilised for pre-emptive interventions in the case of Prevent, unlike other forms of actuarial analysis and risk prediction, are premised as predictive even though there is no evidence that psychological vulnerability, wondering about identity or adopting a conservative version of Islam, such as Salafism, makes one at risk of radicalisation. They are simply too generic and vague to be of use in making professional judgements or diagnoses.

Another explicit aim of Prevent and Channel is to offer counter-narratives and to challenge certain kinds of ideological or theological ideas as part of a wider intervention to counter (nonviolent) extremism. This suggests that the rationale for pre-emptive interventions is understood probabilistically because the discourse of vulnerability in counter-terrorism explicitly and implicitly invokes the spectre of potential danger and risk should an intervention not take place. After all, the purpose of Prevent is to address the numbers of those leaving to fight in Syria and elsewhere and to address the 'home-grown' threat of domestic terrorism. It is an explicitly pre-emptive and preventative strategy, relying on probabilistic risk factors and fitting within a wider pre-crime approach based on surveillance, prevention and risk assessment (McCulloch and Pickering, 2009; Mythen, 2012; Palmer, 2012).

\section{Illegitimate incursions: the Ubu}

The reason, then, that it can be very difficult to speak freely in a context of pre-emptive interventions, such as that advocated by the Prevent Strategy, is clear once we understand how risk is assessed. This strategy also risks silencing those who might wish to contest referrals or who are fearful of the implications of being assessed. McCulloch and Pickering (2009) state that

[p]re-crime suggests that no crime has been committed, while simultaneously evoking the crime that hasn't happened. Crime and pre-crime exist together as matter to shadow. Imagination animated through prejudice and stereotypes rather than objective fact or evidence that point to those facts form the basis of police and security intelligence action and even prosecution under counter-terrorism pre-crime frameworks. (p. 641) 
Foucault's concept of the $U b u$ allows us to examine the implications of, and rationale for, the incursion of a counter-terrorist agenda into the educational domain. As Brian Collins notes, citing Foucault, 'It is difficult to argue against Foucault when he states that "discourses of truth that provoke laughter and have the institutional power to kill are, after all, in a society like ours, discourses that deserve some attention"' (Foucault, 2003: 6, cited in Collins, 2014: 100). What is vital for us in Foucault's (2003) definition of the grotesque or the ubuesque is the following:

the fact that, by virtue of their status, a discourse or an individual can have effects of power that their intrinsic qualities should disqualify them from having. The grotesque, or, if you prefer, the ' $U b u$-esque' is not just a term of abuse or an insulting epithet, and I would not like to use it in that sense. I think that there is a precise category, or, in any case, that we should define a precise category of historico-political analysis, that would be the category of the grotesque or $U b u$-esque. $U b u$-esque terror, grotesque sovereignty, or, in starker terms, the maximization of effects of power on the basis of the disqualification of the one who produces them. (p. 11; my emphasis)

Why does this matter? If we read Prevent through the lens of Foucault, we find a discourse (of security) entering the sphere of education, however, those charged with enacting the duties of securing the State, that is, front-line public sector workers, are simply not qualified to do so. While I do not wish to suggest that educators are generally ' $u b u s$ ', in this instance, when it comes to being mobilised as vehicles for preventing terrorism (rather than educating their students), they fulfil Foucault's (2003) criterion of 'the maximization of effects of power on the basis of the disqualification of the one who produces them' (p. 11). Collins (2017) writes,

These are parasitic discourses because they belong to the interstice between paranoiac structures or if you like power/knowledge and knowledge/power arrangements. The discourse of the psychiatric expert neither belongs to law nor medicine its function is to allow the accused to be punished not on the basis of his crime but on the basis of his biography, on the basis of his life.

Even though reasons for deciding to pursue Channel referrals are not shared on the grounds of national security and the guidelines lack specificity, educators and schools are still expected to meet their duties under Prevent, including identifying students at risk of radicalisation.

We have already discussed the problematic way in which Prevent, as a counter-terrorist strategy, targets extremist ideas in educational institutions. Looking at the duty through the lens of the concept of the $U b u$ may help us to ascertain whether, and if so, to what extent, Prevent has also smuggled an infra-legal and para-pathological framework into the domain of education, one that intensifies anticipatory and pre-crime logics by invoking safeguarding and pastoral care without specifying what one is supposed to safeguard against. In this respect, discourses, experts and concepts from other domains, such as psychiatry and social work, are taken up to operate as a mediator or intermediary that allows security and counter-terrorism discourse and practice into the domain of education, this despite the fact that the Home Office has struggled to define key terms such as 'extremism' and 'extremist' in such a way that such definitions would not be challenged in court. The duty to report students at 'risk of radicalisation' could well be seen as not only illegitimate but also illegal, were it not mediated by psychological and psychotherapeutic discourses about vulnerability, safeguarding, well-being, grooming and resilience. Most importantly, a 'series of forms of conduct, of ways of being' (Foucault, 2003: 15) that have nothing to do with violent extremism or terrorism can be presented 'as the cause, origin, motivation, and starting point of the offense' (p. 15) or, in this case, of the potential offence of possibly becoming a terrorist. 
Foucault's (2003) description of the pathologisation of misdeeds that are not illegal but are nonetheless smuggled into the criminal sphere through expert opinion in medico-legal discourse is again useful here. In this case, what is play in terms of diagnosing risk need not rely on explicit instances of deed, idea, action or even stated belief. It is about susceptibility. The technical concept of 'risk factor' is given ontological force by creating the concept of the 'double' of the student -the potential terrorist he or she may become - that is then documented and audited. The difficulty with creating 'doubles' is that they tend to be attended to more than the actual person because of the force of credibility derived from archives of documentation. To be diagnosed as a problematic object, and constituted as such, means that the 'double' (the paperwork and discourses about you) is privileged as a more credible source of knowledge and evidence than your own words and testimony. The actual, living student or the patient who tries to explain himself or herself to those in power may have difficulty in being heard or listened to, given the power of the 'double' in shaping expert opinion. Describing the psychiatric-penal $U b u$, Foucault notes that expert psychiatric opinion allows for a doubling of the individual by introducing a range of judgements and evaluations that have little to do with either the law or the offence of which someone is accused. These include " "psychological immaturity," "a poorly structured personality," "a poor grasp of reality" (Foucault, 2003: 15) and affective imbalance. In this way, a comprehensive profile is created of traits and ways of being that are not themselves illegal but which retrospectively explain or pre-emptively predict criminality. He remarks,

However, what is it that these forms of conduct infringe on if they do not break the law? These objects emerge against a background in which they are measured against an optimum level of development ('psychological immaturity', 'poorly structured personality', 'profound imbalance'), a criterion of reality ('poor grasp of reality'), moral qualities (modesty, fidelity), and ethical rules. (Foucault, 2003: 16)

The pedagogical-securitocratic $U b u$ also invokes psychiatric language to construct a 'psychologico-ethical double' (Foucault, 2003: 16) of the offence of 'at risk of becoming a terrorist' by outlining a set of 'psychological hooks' that describe 'susceptibilities, motivations and contextual influences and together map the individual pathway to terrorism' (HM Government, 2012: 3). The list under Engagement includes

Feeling of grievance and injustice; feeling under threat; a need for identity, meaning and belonging; a desire for status; a desire for excitement and adventure; a need to dominate and control others; susceptibility to indoctrination; a desire for political or moral change; opportunistic involvement; family or friends involved in extremism; being at a transitional time of life; being influenced or controlled by a group; relevant mental health issues. (2012: 3)

In the second category of Intent, there are no indicators of specific intent; instead, more generic indicators are listed, including 'over-identification with a group or ideology; "Them" and "Us" thinking; dehumanization of the enemy; attitudes that justify offending; harmful means to an end; harmful objectives'. Just as with Foucault's description of ubuesque discourse, few of these are illegal, bar perhaps the last two, although even their lack of definition makes it difficult to ascribe intent. However, the effect of the claim to expert opinion here is to 'legitimize, in the form of scientific knowledge, the extension of punitive power to something that is not a breach of the law' (Foucault, 2003: 18). While again I acknowledge that engagement with Channel is on a voluntary basis, it is nonetheless difficult to differentiate the extension of the counter-terrorist agenda from an extension of punitive power.

In the case of pre-crime and preventative approaches to crime, the risk of a (possible) future of becoming a terrorist can be seen to overdetermine the student's situation such that 'present civil 
liberties are weighed against unknown future risks' (Mythen, 2012: 422). By invoking expert opinion and assessing individuals through the framework of a set of vulnerability factors, it is easier to bypass those legal challenges and human rights challenges that would ordinarily preclude the generalised and indeterminate profiling and surveillance of populations. By not calling it 'profiling' and by instead framing interventions under the banner of psychological well-being, resilience, safeguarding and pastoral care, these can be presented as safeguarding measures. However, the uncertainty that it brings for the student of not knowing whether one's thoughts, ideas or words will be seen as suspicious or risky is corrosive. It would thus seem unwise for a student to test boundaries given the potential for labelling and the implications of referral to Channel, despite its voluntary nature.

\section{Listening to the silences}

We have reflected in detail on two of the dangers raised by Prevent's involvement in education. The first was its stated intention to target non-violent extremism, and hence ideas, as part of a counter-terrorist strategy: an alternative approach to engaging with extremism is to see the critical exploration of difficult and complex questions as part of educational practice (Davies, 2014, 2016). The second is the way in which counter-terrorist agendas are smuggled into education through what Foucault calls the ubuesque, an approach that relies on expert opinion to legitimate intervention into the sphere of non-violent extremism and which frames counter-terrorist preventative work as safeguarding, an approach acceptable, unlike surveillance, in the spheres of education, social work and health. I have suggested that the incorporation of a counter-terrorist strategy into educational practice undermines education and leads to pedagogical injustice for two primary reasons. First, it explicitly targets ideas in education, and second, it flags a range of 'signs' as potential risk factors of involvement in terrorism, problematising ways of being that are not only legal but which also constitute important forms of expression and identity for children and young people. In this final section, we will explore some of the potential implications of this.

Mythen (2012) notes that

As well as being vulnerable to attacks and feeling unfairly discriminated against by the police, participants in the study were aggrieved that their views were infrequently listened to. They described a range of speech gaps ranging from being unable to openly share political opinions, to a lack of representation in public affairs and a feeling of being ignored by the government in the formation of security policies. (p. 419)

In this final section, we will reflect on speech gaps and self-censorship in the context of the work of Miranda Fricker on silence and institutional prejudice. Fricker (2012) writes,

An intelligent ideal of a practice is one informed by risk, and what it takes to guard against it. By contrast to the traditional ideal of testimony, our more informed ideal includes crucial information about a type of risk that is endemic to testimonial practice - namely, the risk that prejudice is allowed to depress the level of credibility given to certain speakers, with the result that an injustice is done and knowledge is missed. (p. 304)

What then does it mean, not just to lack epistemic credibility, or to find that one's testimonial credibility is depressed with the consequence not only of loss of knowledge to oneself but also of a loss of that insight and knowledge to others, but to feel one must not speak for fear of being misread. Elaborating Fricker's concepts relating to epistemic injustice, Medina outlines her understanding of social produced silences based on identity prejudices. The first involves pre-emptive silence that excludes someone from participation. This is context-dependent so even where there is 
participation it may be that some people's contributions are valued more than others. In the second case of silencing, the person is treated as an informant but not as a subject in his or her own right (Medina, 2012: 203). Medina argues that silencing must be seen as both an epistemic and communicative problem, given the struggles to make sense 'in which issues of credibility and issues of intelligibility are intertwined' (pp. 205-206). If we reflect once more on our example of Foucault's $U b u$, we can see the difficulties some will face in making themselves understood if their views are not deemed credible and intelligible by the (non)experts who are assessing them. This situation can also arise in classrooms when educators privilege some voices and stories over others.

Fricker (2012) draws our attention 'to the imposed silence of those who are in some way prevented from making their voices heard' and to what it means to be really listened to when the silence of the listener involves 'a moral attitude of attention to others - an openness to who they are and to what they have to say' (p. 287). It seems to me that evaluating the impact of counterterrorist strategies in education must give due regard to both of these aspects of silence and silencing, in particular if those strategies risk undermining the educator's capacity to listen attentively, carefully and with sensitivity to his or her students. The example Fricker uses to explain institutional prejudice and its relation to silence is the case of Duwayne Brooks, Stephen Lawrence's friend who was present at his murder. First, he was pre-emptively silenced in that the police did not solicit information from him at the scene, and second, he was not properly heard. She views these as central forms of testimonial injustice. I am also minded here of how it would feel to be not listened to, to be misheard or misinterpreted, or to feel stereotyped in the case of the implementation of counter-terrorist strategies in the classroom, or to feel under suspicion or surveillance outside the classroom. In this regard, Fricker's suggestion for how we might listen to others is helpful. She says that 'what individuals must aim to achieve is a certain critical openness to the word of others by way of an unprejudiced perception of those others as individuals' (Fricker, 2012: 9). Following Weil and Murdoch, she describes this perceptiveness as loving attention.

What prevents this from happening? What kinds of institutional prejudices prevent us from hearing others, leading to silencing of some, often on the basis of collective forms of prejudice or racism? Fricker approaches this question in an unusual way by adapting a concept of political freedom that understands freedom as non-domination (Petitt, 1997) and which depends on the power to contest. In our case, it is to be able to contest CONTEST and for people to feel that they are properly heard, without prejudice in so doing. In this respect, institutional bodies must possess the virtue of testimonial justice (Fricker, 2012: 301). In previous sections, I have outlined in detail a number of the ways in which the conditions for testimonial injustice and freedom of speech can be undermined in institutions, in particular through silencing. I have also indicated some of the ways in which we, as educators and as students, can fail to listen to and pay attention to one another without prejudice, including through the deployment of risk factors in the case of educators. I would like to conclude with some brief reflections on what it would mean to think and act otherwise.

Hannah Arendt was profoundly suspicious of those behavioural approaches that sought to eliminate risk from the world. Much of what she writes has a bearing on how we might think about our question of pedagogical injustice. For her, thinking is a dangerous and destructive activity that rids us of clichés, prejudices and preformed opinions. This is why it is particularly necessary at times of crisis and political and moral conformity when we need to think without a banister. She states that the 'banality of evil' stems from the inability to think - what she calls 'thoughtlessness' - and hence to have a conscience. The relationship between consciousness and conscience involves the two-in-one dialogue that Socrates describes as an ongoing process of questioning and examining oneself. It is Eichmann's superficiality, thoughtlessness and reiteration of cliché, in short his thoughtlessness, that she saw as linked to his lack of conscience. I worry that the presumption that we must challenge extremist ideas in order to prevent terrorism precludes the far more important 
exercises that we engage in classrooms when we train our imaginations to go visiting. While Arendt is not thinking about this in educational terms, in our current context, I think visiting is of value as a 'methodology' for thinking together. Arendt values plurality and the doxa or opinions the many ways we have of seeing our shared world, but her position is not one of liberal tolerance. Drawing from Kant's Third Critique, she generates a concept of representative thinking qua enlarged mentality which she describes as follows:

The more people's standpoints I have present in my mind when I am pondering a given issue, and the better I can imagine how I would feel and think if I were in their place, the stronger will be my capacity for representative thinking and the more valid my conclusions, my opinion. (Arendt, 1961: 241)

Rather than fixating on 'challenging' extremist ideas, which assumes a position of certainty in one's own worldview, how would it be to imagine the world from the standpoint of another, indeed of many others? This exercise does not involve empathy, trying to feel like or be someone else, but rather 'training one's imagination to think of oneself from standpoints other than one's own, by thinking and feeling in my identity where actually I am not' (Arendt, 1961: 241). She says, 'To exercise this mentality permits you to take into account the perspectives of others as well as their circumstances' (Arendt quoted in Disch, 1994: 154). Disch (1994) says that for Arendt representation is about creating distance, but visiting bridges distance "to that which is strange and familiar, so that I can look upon it "as though it were my own affair"'(p. 158). As we visit, we construct stories of events from a plurality of perspectives and imagine how we might respond 'as a character in a story very different from my own' (Disch, 1994: 158). Critical thinking, storytelling and visiting involve the work of the imagination that 'distance me from the familiar and take me to standpoints that are unfamiliar' (Disch, 1994: 160). The concern with our shared world, our common world and publicity, the spaces in which we appear to one another, might seem to have little to do with education, at least for Arendt, yet her interest in poetry, literature, history, storytelling and so on suggest otherwise. Why not allow students' imaginations to go visiting, not to one standpoint, to be sure, but to many standpoints, in order to bring a plurality into thought, extending their capacity for an enlarged mentality that refuses single truths while also supporting the conditions for judgement? Todd and Säström (2008) write,

If disagreement, dissent, and conflict are necessary to democracy, then the challenge for educators is to offer those hospitable conditions - no matter how conditional - whereby students can learn that holding a view passionately does not disqualify them from participating meaningfully in democratic forms of life. (p. 9)

They do not say that this is the aim of education, but rather that this kind of education allows for meaningful participation in democratic forms of life.

Writing of 'going visiting', Ann Sharp (2014) says,

Ultimately, our final judgement is located in our relationship to the myriad of views we have taken into account. It is a process that is always dialogical. It is an imaginative and courageous act for children to step back in order to engage in the deliberation that precedes considered judgement. It involves actively trying to remove our own biases and prejudices so that we can listen to others and attempt to understand where they are coming from, what they are assuming, how they see the world. It also involves having the courage to try to bridge the abyss of remoteness so that one can perceive and understand things that at first seem so strange and foreign. (p. vi)

Might this not be a better way of creating positive virtues in educational institutions helping to secure against the kinds of prejudice and silencing that risk such institutions becoming sites of 
pedagogical injustice? Such an approach to education does not eschew conflict but rather invites agonistic positions, as opposed to antagonistic violence (Todd and Säström, 2008: 3), viewing disagreement as an essential dimension of classroom life. To enact this demands critical thinking, imagination and understanding that the other will have a position different from mine. By understanding the potential for agonism through Arendt's concept of visiting, we are not confined by the demands of consensual argumentation but are able to see that conflict is part of the human condition.

Counter-terrorist strategies should be concerned with the prevention of political violence not the policing of ideas, including those ideas seen as extremist. Schools and universities are the right sorts of places for robust and reflective exchanges and interrogations of ideas and positions. Creating communities of enquiry means they also perform a further pedagogical function of asking students to take up different positions and enlarge their thinking, but this is for the sake of education and for the sake of the students, not in the service of security.

\section{Declaration of Conflicting Interests}

The author(s) declared no potential conflicts of interest with respect to the research, authorship, and/or publication of this article.

\section{Funding}

The author(s) received no financial support for the research, authorship, and/or publication of this article.

\section{References}

Arendt H (1955) Men in Dark Times. New York: Harcourt.

Arendt H (1958) The Human Condition. Chicago, IL: University of Chicago Press.

Arendt H (1961) Between Past and Future. New York: Viking Press.

Arendt H (1971) Life of the Mind. New York: Harcourt.

Arendt H (1990) Philosophy and politics. Social Research 57(1): 73-103.

Arendt H (1991) Lectures on Kant's Political Philosophy. Chicago, IL: University of Chicago Press.

Awan I (2012) 'I am a Muslim not an Extremist': how the prevent strategy has constructed a 'suspect' community. Politics and Society 40(6): 1158-1185.

Bartlett J and Birdwell J (2010) From suspects to citizens: preventing violent extremism in a big society. Demos, July. Available at: http://www.demos.co.uk/files/From_Suspects_to_Citizens_-_web. pdf?1279732377 (accessed 10 March 2015).

Belaon A (2015) Building Distrust: Ethnic Profiling in Primary Schools. London: Claystone Press.

Blackwood L, Hopkins N and Reicher S (2016) From theorising radicalization to surveillance practices: Muslims in the cross hairs of scrutiny. Political Psychology 37(5): 597-612.

Burchell G, Gordon C and Miller P (eds) (1991) The Foucault Effect: Studies in Governmentality. Chicago, IL: University of Chicago Press.

Code L (2006) Ecological Thinking: The Politics of Epistemic Location. Oxford: Oxford University Press.

Collins B (2014) Autonomy in Education. Masters by Research, Mary Immaculate College, University of Limerick. Available at: https://dspace.mic.ul.ie/xmlui/handle/10395/2010

Collins B (2017) Foucault's Ubu. Unpublished Manuscript.

Davies L (2014) Interrupting extremism by creating educative turbulence. Curriculum Inquiry 44(4): $450-468$.

Davies L (2016) Security, extremism and education: safeguarding or surveillance? British Journal of Educational Studies 64(1): 1-19.

Department for Children, Schools and Families (2008) Learning Together to be Safe. London: Crown.

Department for Education (2016) Keeping Children Safe in Education: Statutory Guidance for Schools and Colleges. London: Crown.

Disch L (1994) Hannah Arendt and the Limits of Philosophy. New York: Cornell University Press. 
Foucault M (2003) Abnormal: Lectures at the Collége de France 1974-1975. London: Verso Books.

Fricker M (2007) Epistemic Injustice: Power and the Ethics of Knowing. Oxford: Oxford University Press.

Fricker M (2012) Silence and institutional prejudice. In: Crasnow S and Superson A (eds) Out from the Shadows: Analytical Feminist Contributions to Traditional Philosophy. Oxford: Oxford University Press, 287-305.

Hengehold L (2007) The Body Problematic: Political Imagination in Kant and Foucault. University Park, PA: Pennsylvania State University Press.

HM Government (2012) Channel: Vulnerability Assessment Framework. London: Crown Copyright.

HM Government (2015a) Channel Duty Guidance: Protecting Vulnerable People from Being Drawn into Terrorism. London: Crown Copyright.

HM Government (2015b) Revised Prevent Duty Guidance for England and Wales. London: Crown Copyright. Horgan J (2008) From profiles to Pathways and roots to Routes: perspectives from psychology on radicalization into terrorism. The ANNALS of the American Academy of Political and Social Science 618: 80-94.

House of Commons Home Affairs Committee (2016) Radicalisation: The Counter-Narrative and Identifying the Tipping Point. London: House of Commons.

House of Lords, House of Commons, Joint Committee on Human Rights (2016) Counter-Extremism: Second Report of Session 2016-2017. HL Paper 39, HC 105. Published on 22 July 2016 by authority of the House of Lords and the House of Commons.

Human Rights Watch UK (2016) Preventing Education? Human Rights and UK Counter-Terrorism Policy in Schools. London: RWUK.

McCulloch J and Pickering S (2009) Pre-crime and counter-terrorism: imagining future crime in the 'war on terror'. British Journal of Criminology 49: 628-645.

Medina J (2012) Hermeneutical injustice and polyphonic contextualism: social silences and shared hermeneutical responsibilities. Social Epistemology 26(2): 201-220.

Mythen G (2012) 'No one speaks for us': security policy, suspected communities and the problem of voice. Critical Studies on Terrorism 5(3): 409-424.

Mythen G, Walklate S and Khan F (2012) 'Why should we have to prove we're alright?': counter-terrorism, risk and partial securities. Sociology 47(2): 383-398.

O'Donnell A (2016) Contagious ideas: vulnerability, epistemic injustice and counter-terrorism in education. Educational Philosophy and Theory. Epub ahead of print 16 September. doi: 10.1080/00131857.2016.1217187.

Open Society Justice Initiative (OSJI) (2016) Eroding Trust: The UK's Prevent Counter-Extremism Strategy in Health and Education. New York: Open Society Foundation.

O'Toole T, Meer N, Nilsson DeHanas D, et al. (2016) Governing through prevent? Regulation and contested practice in state-Muslim engagement. Sociology 50: 160-177.

Palmer P (2012) Dealing with the exceptional: pre-crime anti-terrorism policy and practice. Policing and Society: An International Journal of Research and Policy 22(4): 519-537.

Pantazis C and Pemberton S (2009) From the 'old' to the 'new' suspect community: examining the impacts of recent UK counter-terrorist legislation. British Journal of Criminology 49: 646-666.

Petitt P (1997) Republicanism: A Theory of Freedom and Government. Oxford: Oxford University Press.

Rights Watch UK (2016) Preventing Education? Human Rights and UK Counter-Terrorism Policy in Schools. London: Rights Watch UK.

Rose N (2004) Powers of Freedom: Reframing Political Thought. Cambridge: Cambridge University Press.

Schinkel W (2011) Prepression: the actuarial archive and new technologies of security. Theoretical Criminology 15(4): 365-390.

Sharp CA (2014) Foreword in Philosophy with Teenagers (ed P Hannam and E Echeverria). London: Continuum.

Sukarieh M and Tannock S (2015) The deradicalisation of education: terror, youth and the assault on learning. Race \& Class 57(4): 22-38.

Todd S and Säström C (2008) Democracy, education and conflict: rethinking respect and the place of the ethical. Journal of Educational Controversy 3(1): 12. Available at: http://cedar.wwu.edu/jec/vol3/iss1/12

Van San M, Siekelinck S and Winter M (2013) Ideals adrift: an educational approach to radicalization. Ethics and Education 8(3): 276-289. 